Article

\title{
Preclinical Evaluation of the Antimicrobial- Immunomodulatory Dual Action of Xenohormetic Molecules against Haemophilus influenzae Respiratory Infection
}

\author{
Ariadna Fernández-Calvet ${ }^{1,+}{ }^{\mathbb{D}}$, Begoña Euba ${ }^{1,2,+}$, Lucía Caballero ${ }^{1}$, Roberto Díez-Martínez ${ }^{3} \mathbb{D}$, \\ Margarita Menéndez ${ }^{2,4}\left(\mathbb{D}\right.$, Carlos Ortiz de Solórzano ${ }^{5,6} \mathbb{D}^{\text {, José Leiva }}{ }^{7,8}$, Vicente Micol ${ }^{9,10}(\mathbb{D}$, \\ Enrique Barrajón-Catalán ${ }^{9}(\mathbb{D})$ and Junkal Garmendia ${ }^{1,2, *}$ \\ 1 Instituto de Agrobiotecnología, CSIC-Gobierno Navarra, 31192 Mutilva, Spain; \\ ariadna.fernandez@unavarra.es (A.F.-C.); beuba@alumni.unav.es (B.E.); luciacaballero21@gmail.com (L.C.) \\ 2 Centro de Investigación Biomédica en Red de Enfermedades Respiratorias (CIBERES), 28029 Madrid, Spain; \\ mmenendez@iqfr.csic.es \\ 3 Ikan Biotech SL, The Zebrafish Lab, Centro Europeo de Empresas e Innovación de Navarra (CEIN), 31110 \\ Noain, Spain; roberto.diez@ikanbiotech.com \\ 4 Instituto de Química Física Rocasolano, CSIC, 28006 Madrid, Spain \\ 5 Laboratory of Preclinical Models and Analytical Tools, Division of Solid Tumors and Biomarkers, Center for \\ Applied Medical Research, 31008 Pamplona, Spain; codesolorzano@unav.es \\ 6 Centro de Investigación Biomédica en Red de Enfermedades Oncológicas (CIBERONC), 28029 Madrid, Spain \\ 7 Servicio de Microbiología, Clínica Universidad de Navarra, 31008 Pamplona, Spain; jleiva@unav.es \\ 8 Instituto de Investigación Sanitaria de Navarra (IdiSNA), 31008 Pamplona, Spain \\ 9 Instituto de Investigación, Desarrollo e Innovación en Biotecnología Sanitaria de Elche (IDiBE), Instituto de \\ Biología Molecular y Celular (IBMC), Miguel Hernández University, 03203 Elche, Spain; \\ vmicol@umh.es (V.M.); e.barrajon@umh.es (E.B.-C.) \\ 10 Centro de Investigación Biomédica en Red de Fisiopatología de la Obesidad y Nutrición (CIBERobn), \\ 28029 Madrid, Spain \\ * Correspondence: juncal.garmendia@csic.es; Tel.: +34-948168484; Fax: +34-948232191 \\ + These authors contributed equally to this work.
}

Received: 18 November 2019; Accepted: 12 December 2019; Published: 17 December 2019

\begin{abstract}
Chronic obstructive pulmonary disease (COPD) is characterized by abnormal inflammation and impaired airway immunity, providing an opportunistic platform for nontypeable Haemophilus influenzae (NTHi) infection. In this context, therapies targeting not only overactive inflammation without significant adverse effects, but also infection are of interest. Increasing evidence suggests that polyphenols, plant secondary metabolites with anti-inflammatory and antimicrobial properties, may be protective. Here, a Cistus salviifolius plant extract containing quercetin, myricetin, and punicalagin was shown to reduce NTHi viability. Analysis of these polyphenols revealed that quercetin has a bactericidal effect on NTHi, does not display synergies, and that bacteria do not seem to develop resistance. Moreover, quercetin lowered NTHi airway epithelial invasion through a mechanism likely involving inhibition of Akt phosphorylation, and reduced the expression of bacterially-induced proinflammatory markers il-8, cxcl-1,il-6, pde4b, and tnf $\alpha$. We further tested quercetin's effect on NTHi murine pulmonary infection, showing a moderate reduction in bacterial counts and significantly reduced expression of proinflammatory genes, compared to untreated mice. Quercetin administration during NTHi infection on a zebrafish septicemia infection model system showed a bacterial clearing effect without signs of host toxicity. In conclusion, this study highlights the therapeutic potential of the xenohormetic molecule quercetin against NTHi infection.
\end{abstract}


Keywords: polyphenol; xenohormesis; Haemophilus influenzae; antimicrobial; anti-inflammatory; respiratory infection

\section{Introduction}

Chronic obstructive pulmonary disease (COPD) is an irreversible lung disease, typically caused by cigarette smoking [1]. Airflow limitation in COPD associates with chronic inflammation of the respiratory tract, a result of repeated insult by noxious components of cigarette smoke [2,3]. Respiratory inflammation is further increased in COPD patients during periods of exacerbation, which are events induced by infection in most instances [4]. The colonizing opportunistic pathogen nontypeable Haemophilus influenzae (NTHi) is implicated in COPD exacerbations, and frequently isolated from respiratory samples $[5,6]$. Repeated episodes of exacerbation and the ensuing inflammation contribute to lung damage and progressive airflow limitation, often resulting in hospitalization or death, and placing an enormous burden on health services [7-9].

COPD management relies on lifestyle changes, use of bronchodilators, inhaled corticosteroids (ICS), and antibiotic administration for infectious exacerbations. ICS are the mainstay of anti-inflammatory therapy, but their usefulness in COPD has been questioned due to potential side effects such as an increased risk of pneumonia [10-12] and corticosteroid insensitivity due to oxidative stress from cigarette smoke and chronic inflammation [13]. Long-acting bronchodilators, alone or in combination with ICS, phosphodiesterase-4 inhibitors, and lung volume reduction surgery have proven to reduce exacerbations, but a significant number of patients continue to experience acute episodes [14]. Hence, there is high demand for effective treatments to target COPD chronic inflammation, as it is hoped that reducing inflammation will lead to improved quality of life for patients and possibly reduce exacerbation frequency [15]. However, therapeutic modulation of the host immunity requires a fine-tuned balance because the same cells, molecules, and mechanisms involved in host protection can also be involved in deleterious inflammation. Moreover, excessive anti-inflammatory effects may dampen immune responses, thus facilitating infectious processes. In this context, therapies targeting not only overactive inflammation without significant adverse effects, but also infection are of particular translational significance. This is the case with macrolide antibiotics, which have anti-inflammatory effects beyond their antimicrobial activity. However, although high quality randomized controlled trials confirm that long-term azithromycin treatment decreases the risk of COPD exacerbations, careful attention needs to be paid to the potential risks of hearing decrements, cardiac toxicity, and development of microbial resistance patterns [14-16].

Plant metabolites acting as xenohormetic molecules are drug candidates to follow this demand, and therefore the focus of this study. Hormesis is an adaptive response in which heterotroph exposure to low doses of plant chemical compounds has a beneficial and/or adaptive effect. This response can be mediated by molecules that, when incorporated in the heterotroph diet, induce biological responses leading to pharmacological effects. Xenohormesis is this final effect as a benefit obtained by the heterotroph organism, giving us opportunities to obtain benefits from natural compounds as drugs naturally selected through evolutionary processes [17]. In particular, plant polyphenols are a large group of natural molecules with antioxidant, chelating, and anti-inflammatory properties. These molecules, which are important components of human diet, have potential benefits for cancer, cardiovascular disease, and other chronic diseases involving oxidative stress or inflammation such as rheumatoid arthritis and COPD [18,19]. In fact, high intake of catechins and solid fruits has shown a beneficial effect in COPD [20]; some plant lignans suppress the inflammatory response in cigarette smoke-stimulated airway epithelial cells and in a COPD murine model [21], and the polyphenols curcumin and quercetin attenuate cigarette smoke induced pulmonary inflammation and mouse emphysema [22,23]. Some polyphenols are also antimicrobials and may have synergistic effects, either by themselves or in combination with conventional antibiotics [24-29]. Thus, the polyphenol resveratrol 
has a protective role in respiratory disease, with anti-inflammatory, antioxidant, and antibacterial properties [30-32].

Following the interest in drugs targeting both overactive inflammation and infection, we previously evaluated the effect of azithromycin, showing that its efficacy on infection by NTHi highly relates to the minimal inhibitory concentration of the infecting strain [33], and of resveratrol, showing a protective role in NTHi infection [30]. Together, the existing evidence prompted us to screen the antibacterial effect of a panel of plant extracts with known polyphenolic composition, and to characterize the antimicrobial-immunomodulatory dual action of their specific polyphenols. Cistus salviifolius extract, which contains quercetin, myricetin, punicalagin, and ellagic acid as main polyphenols, reduced NTHi viability. Polyphenol analysis showed a quercetin in vitro bactericidal effect, without being prone to develop resistance. Quercetin effects were further tested on NTHi infected cultured airway epithelial and phagocytic cells, and on NTHi lung infection and septicemia in vivo model systems. The potential usefulness of modulating the host immune responses by using antimicrobial xenohormetic molecules such as quercetin is discussed.

\section{Materials and Methods}

\subsection{Bacterial Strains, Media, Growth Conditions, and Drugs}

NTHi strains were grown at $37^{\circ} \mathrm{C}, 5 \% \mathrm{CO}_{2}$ on PVX agar (Biomérieux), or on Haemophilus Test Medium (HTM) Base agar (Oxoid) supplemented with $10 \mu \mathrm{g} / \mathrm{mL}$ hemin and $10 \mu \mathrm{g} / \mathrm{mL}$ nicotinamide adenine dinucleotide (NAD) (Sigma-Aldrich), referred to as SHTM agar. NTHi liquid cultures were grown in brain heart infusion (BHI) (Oxoid) supplemented with $10 \mu \mathrm{g} / \mathrm{mL}$ hemin and $10 \mu \mathrm{g} / \mathrm{mL}$ NAD, referred to as sBHI. NTHi375 is a clinical isolate from the middle ear of a pediatric patient with otitis media [34]. When necessary, bacterial viability upon host cell infection conditions was tested. To do so, phosphate-buffered saline (PBS)-normalized bacterial suspensions $\left(\mathrm{OD}_{600}=1 \sim 10^{9}\right.$ c.f.u. $\left./ \mathrm{mL}\right)$ were prepared by using NTHi grown on PVX agar, $100 \mu \mathrm{L}$ aliquots were incubated in $1 \mathrm{~mL}$ Earle's Balanced Salt Solution (EBSS, Gibco) medium in the absence/presence of selected polyphenol concentrations for $2 \mathrm{~h}$ at $37^{\circ} \mathrm{C}$, serially diluted, and plated on sHTM agar for c.f.u./mL determination. When necessary, heat killed (HK) bacteria were used. For this purpose, a bacterial suspension was recovered from a freshly grown PVX agar plate with $1 \mathrm{~mL}$ PBS, adjusted to $\mathrm{OD}_{60}=1$ and incubated at $80^{\circ} \mathrm{C}$ for $30 \mathrm{~min}$. Ampicillin (Amp, Sigma-Aldrich) and azithromycin dihydrate (Azm, Zytromax) $10 \mathrm{mg} / \mathrm{mL}$ stock solutions were prepared in distilled $\mathrm{H}_{2} \mathrm{O}\left(\mathrm{dH}_{2} \mathrm{O}\right)$ and filtered. Four plant extracts rich in polyphenols were used: Cistus salviifolius extract (45\% w/w polyphenols) was obtained as previously described [35]; Punica granatum extract ( $20 \% w / w$ punicalagins) was provided by Nutracitrus S.L. (Elche, Spain); Hibiscus sabdariffa ( $6 \%$ w/w polyphenols) and Lippia citriodora (30\% w/w phenylpropanoids) extracts were provided by Nutrafur S.L. (Alcantarilla, Spain). These extracts were used by preparing $5 \mathrm{mg} / \mathrm{mL}$ stock solutions, as follows: P. granatum, L. citriodora and $\mathrm{H}$. sabdariffa extracts were dissolved in $\mathrm{dH}_{2} \mathrm{O}$ and filtered; $C$. salviifolius extract was dissolved in $\mathrm{dH}_{2} \mathrm{O}$ :DMSO $(9: 1, v / v)$ and sonicated in an ultrasonic bath for $1 \mathrm{~min}$. Plant extract stocks were freshly prepared prior use. Quercetin (purity $\geq 95 \%$ ), myricetin (purity $\geq 96 \%$ ) (Sigma-Aldrich) and punicalagin (A+B mixture, product \#80524 PhytoLab) were used by preparing $10 \mathrm{mg} / \mathrm{mL}$ stock solutions in methanol (for "only bacteria" assays) or DMSO (for host cell infection and in vivo assays), and preserved at $-20^{\circ} \mathrm{C}$ until use. Antibiotic, plant extract, and pure polyphenol working concentrations are specified in each type of assay (see below).

\subsection{Determination of Plant Extract and Pure Polyphenol Antimicrobial Effects}

A broth microdilution assay was developed to determine minimal inhibitory concentrations (MIC). To do so, $500 \mu \mathrm{g} / \mathrm{mL}$ working solutions were prepared in sBHI for P. granatum, L. citriodora and H. sabdariffa extracts, and for quercetin, myricetin, and punicalagin; differently, a C. salviifolius 500 $\mu \mathrm{g} / \mathrm{mL}$ working solution was prepared in PBS. Then, $120 \mu \mathrm{L}$ aliquots were transferred to individual wells in column 1 of 96 -well microtiter plates. A vehicle solution control consisting of a volume of $\mathrm{dH}_{2} \mathrm{O}$, 
$\mathrm{dH}_{2} \mathrm{O}: \mathrm{DMSO}(9: 1, v / v)$ or methanol, equivalent to that used for the highest plant extract/polyphenol concentration tested, was performed in parallel. From columns 2 to $12,80 \mu \mathrm{L}$ aliquots of sBHI were transferred to individual wells when performing P. granatum, L. citriodora, H. sabdariffa, quercetin, myricetin, and punicalagin assays, and $80 \mu \mathrm{L}$ aliquots of PBS were transferred to individual wells when performing C. salviifolius assays. Next, $40 \mu \mathrm{L}$ serial dilutions were made from columns 1 to 12 , by discarding $40 \mu \mathrm{L}$ from column 12 , to have $80 \mu \mathrm{L}$ per well in all cases. When the MIC values ranged between 500 and $167 \mu \mathrm{g} / \mathrm{mL}$, a range of intermediate concentrations was manually prepared. A suspension of PVX agar freshly grown bacteria was generated in PBS (to be used for testing P. granatum, L. citriodora, $H$. sabdariffa extracts, and quercetin, myricetin and punicalagin polyphenols) or in sBHI (to be used for testing $C$. salviifolius extract), adjusted to $\mathrm{OD}_{600}=1$, serially diluted in PBS or sBHI, respectively to $10^{-6}$. Then, $20 \mu \mathrm{L}$ bacterial aliquots were transferred to individual wells. Blank controls (PBS or sBHI without bacteria) were used per each tested sample type and concentration. Plates were incubated for $24 \mathrm{~h}$ at $37{ }^{\circ} \mathrm{C}, 5 \% \mathrm{CO}_{2}$, without agitation. Next, $25 \mu \mathrm{L}$ aliquots of INT-formazan (Sigma-Aldrich, $1 \mathrm{mg} / \mathrm{mL}$ solution prepared in $\mathrm{dH}_{2} \mathrm{O}$ ), were transferred to individual wells. Viable bacteria render a red precipitate after $1 \mathrm{~h}$ incubation at $37^{\circ} \mathrm{C}, 5 \% \mathrm{CO}_{2}$, without agitation. Bacterial survival was quantified by measuring $\mathrm{OD}_{570}$; absorbance values were corrected to their matching blanks values. Percentage (\%) of bacterial survival was calculated according to each corresponding vehicle solution control. At least three independent assays were performed in duplicate $(n \geq 6)$.

\subsection{Determination of Antimicrobial Synergic Effects}

Serial dilutions of each molecule to be tested were prepared in sBHI and combined at different proportions following the checkerboard method [36,37]. Briefly, after generating each polyphenol-polyphenol or polyphenol-antibiotic concentration matrix, each individual well of 96-well microtiter plates contained $80 \mu \mathrm{L}$ final volume. A suspension of PVX agar freshly grown bacteria was generated in PBS, adjusted to $\mathrm{OD}_{600}=1$, serially diluted in PBS to $10^{-6}$, and $20 \mu \mathrm{L}$ aliquots were transferred to individual wells. Plates were incubated for $24 \mathrm{~h}$ at $37^{\circ} \mathrm{C}, 5 \% \mathrm{CO}_{2}$, without agitation. Bacterial viability was determined by using the INT-formazan reagent as readout (see above). It was also used to calculate the fractional inhibitory concentration (FIC) index of each polyphenol-polyphenol or polyphenol-antibiotic combination, and to determine the existence of synergy ( $\Sigma$ FIC $\leq 0.5)$, additive $(0.5>\Sigma F I C \leq 1)$, indifferent $(1>\Sigma F I C<2)$ or antagonic $(\Sigma F I C \geq 2)$ effects. At least 3 independent assays were performed $(n \geq 3)$.

\subsection{Polyphenol Susceptibility Assays}

To assess if the polyphenol antimicrobial effect is bactericidal or bacteriostatic, quercetin, myricetin, and punicalagin solutions with concentrations equivalent to each respective MIC were prepared in sBHI, and $80 \mu \mathrm{L}$ aliquots were transferred to individual wells in 96-well microtiter plates. As a bactericidal control, Amp $4 \mu \mathrm{g} / \mathrm{mL}$ was prepared in sBHI, and $80 \mu \mathrm{L}$ aliquots were transferred to individual wells in 96-well microtiter plates. A vehicle solution control consisting of a volume of methanol equivalent to that used for each polyphenol concentration tested was performed in parallel. A suspension of PVX agar freshly grown bacteria was generated in PBS, adjusted to $\mathrm{OD}_{600}=1$, serially diluted in PBS to $10^{-6}$, and $20 \mu \mathrm{L}$ aliquots were transferred to individual wells in 96-well microtiter plates. Plates were incubated for $24 \mathrm{~h}$ at $37^{\circ} \mathrm{C}, 5 \% \mathrm{CO}_{2}$, without agitation. Next, $20 \mu \mathrm{L}$ aliquots from each well were transferred to their matching wells on a new microplate, where $80 \mu \mathrm{L}$ sBHI aliquots had been previously added. Plates were incubated as before, and bacterial viability determined with the INT-formazan reagent in all cases. Wells with viable bacteria were used for serial dilution, plating on sHTM agar, and c.f.u./mL determination. Three independent assays were performed in quadruplicate $(n=12)$. 


\subsection{Serial Passage Experiment with Polyphenol}

This assay was adapted from [38]. Briefly, quercetin, myricetin, and punicalagin stock solutions prepared in methanol were diluted in sBHI to quercetin, $100 \mu \mathrm{g} / \mathrm{mL}$; myricetin, $256 \mu \mathrm{g} / \mathrm{mL}$; punicalagin, $205 \mu \mathrm{g} / \mathrm{mL}$. Such concentrations are subinhibitory for each tested polyphenol. $80 \mu \mathrm{L}$ of each polyphenol concentration were transferred to individual wells in 96-well microtiter plates. A vehicle solution control consisting of a volume of methanol equivalent to that used for each polyphenol concentration tested was performed in parallel. A suspension of PVX agar freshly grown bacteria was generated in PBS, adjusted to $\mathrm{OD}_{600}=1$, serially diluted in PBS to $10^{-6}$, and $20 \mu \mathrm{L}$ aliquots were transferred to individual wells. Blank controls (PBS) were used per each tested sample type. Plates were incubated for $24 \mathrm{~h}$ at $37^{\circ} \mathrm{C}, 5 \% \mathrm{CO}_{2}$, without agitation. Cultures were then passaged $(20 \mu \mathrm{L}$ in $80 \mu \mathrm{L}$ fresh sBHI with polyphenol or vehicle solution) every day for 15 days. At each time point throughout the cycling, each well absorbance $\left(\mathrm{OD}_{600}\right.$ at $24 \mathrm{~h}-\mathrm{OD}_{600}$ at $\left.0 \mathrm{~h}\right)$ was measured. Four replicates per condition were made in two independent experiments $(n=8)$.

\subsection{Infection of Tissue Cultured Cells}

Carcinomic human alveolar basal epithelial cells (A549, ATTC CCL-185) were maintained as described previously [39], seeded to $1.5 \times 10^{5}$ cells per well (24-well plates) for $32 \mathrm{~h}$, and then serum starved for $16 \mathrm{~h}$ before infection. MH-S murine alveolar macrophages (ATCC CRL-2019) were maintained as described previously [40] and seeded to $5 \times 10^{5}$ cells per well in 24-well plates $16 \mathrm{~h}$ before infection. For infection, PBS-normalized bacterial suspensions $\left(\mathrm{OD}_{600}=1\right)$ were prepared by using NTHi grown on PVX agar. Adhesion, invasion (for A549 cells), and phagocytosis (for MH-S cells) assays were performed as previously described [39-41]. When indicated, cells were pretreated for $4 \mathrm{~h}$ with quercetin or vehicle solution (DMSO) (in EBSS for A549 cells; in RPMI 1640 with 10 mM HEPES and $10 \%$ heat-inactivated FCS for MH-S cells). The polyphenol-containing medium was replaced by polyphenol-free medium prior infection. Alternatively, cells were infected, and quercetin or DMSO was added during the gentamicin $(\mathrm{Gm})$ incubation period. Quercetin did not induce cytotoxicity, determined by measuring the release of lactate dehydrogenase and microscopy (data not shown). Controls (indicated as V in the Figures) were performed by using DMSO volumes corresponding to that of the highest drug concentration tested in each assay. After bacterial infection, wells were washed and cells were lysed as previously described [39]. Lysates were serially diluted in PBS and plated on sHTM agar for bacterial counts. Results are expressed as c.f.u./well. Experiments were performed in triplicate and on at least three independent occasions $(n \geq 9)$.

\subsection{RNA Extraction and Real-Time Quantitative PCR}

A549 cells were pretreated with quercetin/vehicle solution (DMSO) for $4 \mathrm{~h}$, and incubated with HK NTHi (equivalent in numbers to that of the infecting dose, drug exposure was maintained during bacterial-cell contact) for $2 \mathrm{~h}$ in EBSS, as described previously [30]. MH-S cells were pretreated with quercetin/DMSO for $4 \mathrm{~h}$ and incubated with HK NTHi for $1 \mathrm{~h}$ in RPMI 1640 with $10 \mathrm{mM}$ HEPES and $10 \%$ heat-inactivated FCS. Uninfected groups were included as controls. Next, total RNA was isolated from cells using a Nucleospin RNAII kit (Macherey-Nagel, Düren, Germany) as recommended by the manufacturer, and including an on column DNase treatment step. When indicated, total RNA was isolated from mouse lungs using TRIzol reagent (Invitrogen, Carlsbad, CA, USA). Total RNA quality was evaluated using RNA 6000 Nano LabChips (Agilent 2100 Bioanalyzer, Santa Clara, CA, USA). All samples had intact $18 \mathrm{~S}$ and $28 \mathrm{~S}$ ribosomal RNA bands with RNA integrity numbers (RIN) between 7.5 and 10. Reverse transcription was performed using $1 \mu \mathrm{g}$ of RNA by PrimeScript RT Reagent kit (Takara, Shiga, Japan). To amplify human il-6, il-8, cxcl-1, pde4b, gapdh, and mouse $k c$, tnfo, pde $4 b$, gapdh genes, 1:10 diluted cDNA were used as template (including endogenous control). In all cases, $20 \mu \mathrm{L}$ reaction mixtures containing 1X SYBR Premix Ex Taq II (Tli RNaseH Plus) (Takara) and the adequate primer mix were used. Fluorescence data were analyzed with AriaMx Real-Time PCR System (Agilent 
Technologies, Santa Clara, CA, USA). The comparative threshold cycle (Ct) method was used to obtain relative quantities of mRNA that were normalized using human or mouse gapdh as an endogenous control. Intron-spanning primers were designed with Primer-BLAST software (NCBI) (Table S1). All measures were performed in triplicate and at least three times $(n \geq 9)$.

\subsection{Western Blotting}

A549 cells seeded as above indicated were pretreated with quercetin $60 \mu \mathrm{g} / \mathrm{mL}$ or vehicle solution (DMSO) for $4 \mathrm{~h}$ in EBSS, and quercetin was removed prior infection. For infection, PBS-normalized bacterial suspensions $\left(\mathrm{OD}_{600}=1\right)$ were prepared by using NTHi strains grown on PVX agar, and 100 $\mu \mathrm{L}$ aliquots were transferred to each well. Cells were infected for 0 (uninfected), 10, 20, 30, 45 and $60 \mathrm{~min}$. Afterwards, the wells were washed 3 times with cold PBS, lysed with $50 \mu \mathrm{L}$ of lysis buffer ( $62.5 \mathrm{mmol}$ Tris-HCl pH 6.8, 2\% w/v SDS, $10 \%$ glycerol, $50 \mathrm{mmol}$ DTT, $0.01 \% w / v$ bromophenol blue) and scraped on ice. Samples were sonicated, boiled, and cooled on ice before $10 \%$ SDS-PAGE and western blotting. Akt phosphorylation was detected with primary rabbit anti-phosphoSer473 Akt antibody (Cell Signaling Technology, Beverly, MA, USA) diluted 1:1000. Total Akt, used as a loading control, was detected with primary rabbit anti-Akt antibody (Cell Signaling Technology) diluted 1:1000. A secondary goat anti-rabbit antibody conjugated to horseradish peroxidase (Thermo Scientific, Rockford, IL, USA) diluted 1:10000 was used. ECL AdvanceTM Western Blotting Detection Kit (GE HealthCare, Boston, MA, USA) was used for detection. Western blots were performed at least three times by using independently generated cell extracts $(n=3)$. Images corresponding to a representative experiment are shown in the results section.

\subsection{NTHi Mouse Lung Infection}

A mouse model of NTHi lung infection was used as previously described [42]. CD1 female mice (18-20 g) aged 4-5 weeks purchased from Charles River Laboratories (France) were housed under pathogen-free conditions at the Institute of Agrobiotechnology facilities (registration number ES/31-2016-000002-CR-SU-US). Animal handling and procedures were in accordance with the current European and National (RD 53/2013) legislation (Protocol PI 007/19). Emphysema was induced by intratracheal administration of porcine pancreatic elastase (EPC, Elastin Products Company, Owensville, MI, USA). To do so, $10 \mathrm{mg}$ containing 1350 elastase units (U) were resuspended in $10 \mathrm{~mL}$ physiological serum to generate a stock solution $(1 \mathrm{mg} / \mathrm{mL}$, i.e., $135 \mathrm{U} / \mathrm{mL})$. To induce emphysema, one $90 \mu \mathrm{L}$ dose containing 6 elastase $\mathrm{U} /$ mouse was administered 21 days before infection. Quercetin treatment was performed at $60 \mathrm{mg} / \mathrm{kg}$ of body weight in $0.1 \mathrm{~mL}$ PBS-DMSO (1:1) and administered by oroesophageal gavage (Popper\&Sons Inc., Philadelphia, PA, USA). Administrations were performed daily during 8 days before infection ( $1 \mathrm{~h}$ before infection on day 8 ), and at 6,12 and $23 \mathrm{~h}$ post-infection (hpi). Quercetin administration at $6 \mathrm{hpi}$ was performed in mice euthanized at $12 \mathrm{hpi}$; quercetin administration at 6,12 and $23 \mathrm{hpi}$ was performed in mice euthanized at $24 \mathrm{hpi}$. NTHi strain 375 was used for lung infection. Mice were randomly divided into infected and control uninfected groups, and into quercetin-treated and vehicle solution (PBS-DMSO, 1:1)-administered mice. Animals were euthanized at 12 or $24 \mathrm{hpi}$ (n $\geq 6$ per group). For NTHi intranasal infection, $20 \mu \mathrm{L}$ of an exponentially grown $\left(\mathrm{OD}_{600}=0.3\right)$ bacterial suspension containing $\sim 5 \times 10^{9}$ c.f.u./mL $\left(\sim 1 \times 10^{8}\right.$ c.f.u./mouse $)$ was placed at the entrance of the nostrils until complete inhalation by the mouse, previously anesthetized (ketamine-xylazine, 3:1). At the indicated time points, mice were euthanized and lungs were aseptically removed. The left lung was individually weighed in sterile bags (Stomacher80, Seward Medical Ltd., Rhymney, UK) and homogenized 1:10 $(w / v)$ in PBS. Each homogenate was serially 10-fold diluted in PBS and plated in triplicate on sHTM agar to determine the number of viable bacteria. The right lung was homogenized with TRIzol reagent for subsequent RNA extraction as indicated above. 


\subsection{NTHi Adult Zebrafish Infection}

Animal experiments conducted at Ikan Biotech (https://www.ikanbiotech.com) animal housing facility were performed as previously described [30], according to the approval of the Universidad de Navarra (UNAV) Ethics Committee for Animal Experimentation (Protocol 107-19). Quercetin toxicity in zebrafish embryos was tested by performing the OECD TG236 "Fish embryo acute toxicity (FET) test". Once lack of quercetin toxicity in zebrafish was confirmed (data not shown), adult zebrafish were randomly divided into 2 infected (administered quercetin or vehicle solution) and 2 uninfected (administered quercetin or vehicle solution) groups ( $\mathrm{n} \geq 6$ per group). Infected groups were injected with $10 \mu \mathrm{L}$ of a NTHi375 exponentially grown $\left(\mathrm{OD}_{600}=0.3\right)$ suspension containing $\sim 10^{10}$ c.f.u. $/ \mathrm{mL}$ ( $\sim 10^{8}$ c.f.u./zebrafish), prepared in perfusion solution (Grifols, Spain). At 29 and $53 \mathrm{hpi}$, an infected and an uninfected group were intraperitoneally administered quercetin at a dose of $0.3 \mathrm{mg} / \mathrm{g}$ of body weight in $10 \mu \mathrm{L}$ of perfusion solution-DMSO (1:1); the other groups were administered perfusion solution-DMSO (1:1). Survival rate for each group was monitored three times per day for 5 days after infection.

\subsection{Statistical Analysis}

In all cases, $p<0.05$ value was considered statistically significant. Analyses were performed using Prism software, version 7 for Mac (GraphPad Software) statistical package, and are detailed in each Figure legend.

\section{Results}

\subsection{An Extract of Cistus salviifolius Rich in Polyphenols Has an Antimicrobial Effect on H. influenzae}

Cistus salviifolius and Punica granatum extracts, containing ellagitannins and flavonoids, were selected for this study due to their previously seen antibacterial effects [29,43]. Hibiscus sabdariffa and Lippia citriodora extracts were selected based on their antifungal activity and their efficacy against some bacteria [35]. We first tested the susceptibility of the clinical strain NTHi375 to these four plant extracts rich in polyphenols and observed a significant dose-dependent reduction of bacterial viability after incubation with the C. salviifolius extract (Figure 1A). This observation was also made for the reference strain RdKW20, which also showed lower viability at the highest $P$. granatum concentrations tested (Figure S1A). These observations prompted us to analyze the effect of three polyphenols, quercetin, myricetin, and punicalagin, the most representative aglycones of the large variety of glycosylated polyphenols present in the C. salviifolius extract [35]. The three molecules reduced NTHi bacterial viability in a dose-dependent manner, quercetin being the one with the lowest MIC observed (Figure 1B and Figure S1B). Genomic heterogeneity is a known feature for NTHi [44-46], which may lead to variable polyphenol susceptibility among strains, as is shown for other antimicrobials [33]. We evaluated the effect of quercetin, myricetin, and punicalagin on three NTHi clinical strains isolated from COPD sputum samples and belonging to different clonal types [45]; their viability decreased when exposed to polyphenols, with some MIC variations among them (Table S2).

These results support that the extract of $C$. salviifolius and, in particular, three of its containing polyphenols, quercetin, myricetin, and punicalagin, reduce NTHi viability in a dose-dependent manner.

\subsection{Antimicrobial Effects of Quercetin, Myricetin, and Punicalagin against NTHi}

Next, we evaluated if polyphenol effects on NTHi viability are bactericidal or bacteriostatic. NTHi375 cells were incubated with quercetin, myricetin or punicalagin (MIC concentrations, based on observations shown in Figure 1B) for $24 \mathrm{~h}$, bacterial cultures were then diluted into new microplate wells without polyphenol for 24 additional hours, and the number of viable cells was monitored by serial dilution and plating at the indicated time intervals ( 24 and $48 \mathrm{~h}$ ). After $24 \mathrm{~h}$, quercetin, myricetin, and punicalagin-treated cultures showed a lower number of viable cells than the vehicle solution control ones. At $48 \mathrm{~h}$, only quercetin-treated cultures showed a lower number of viable cells than 
the control ones. In contrast, myricetin and punicalagin-treated cultures showed growth numbers comparable to those of the control ones. These results suggested quercetin to be bactericidal, and myricetin and punicalagin to be bacteriostatic on NTHi375 (Figure 1C). Similar results were observed for RdKW20 where, besides quercetin, punicalagin seemed to be bactericidal as well (Figure S1C).
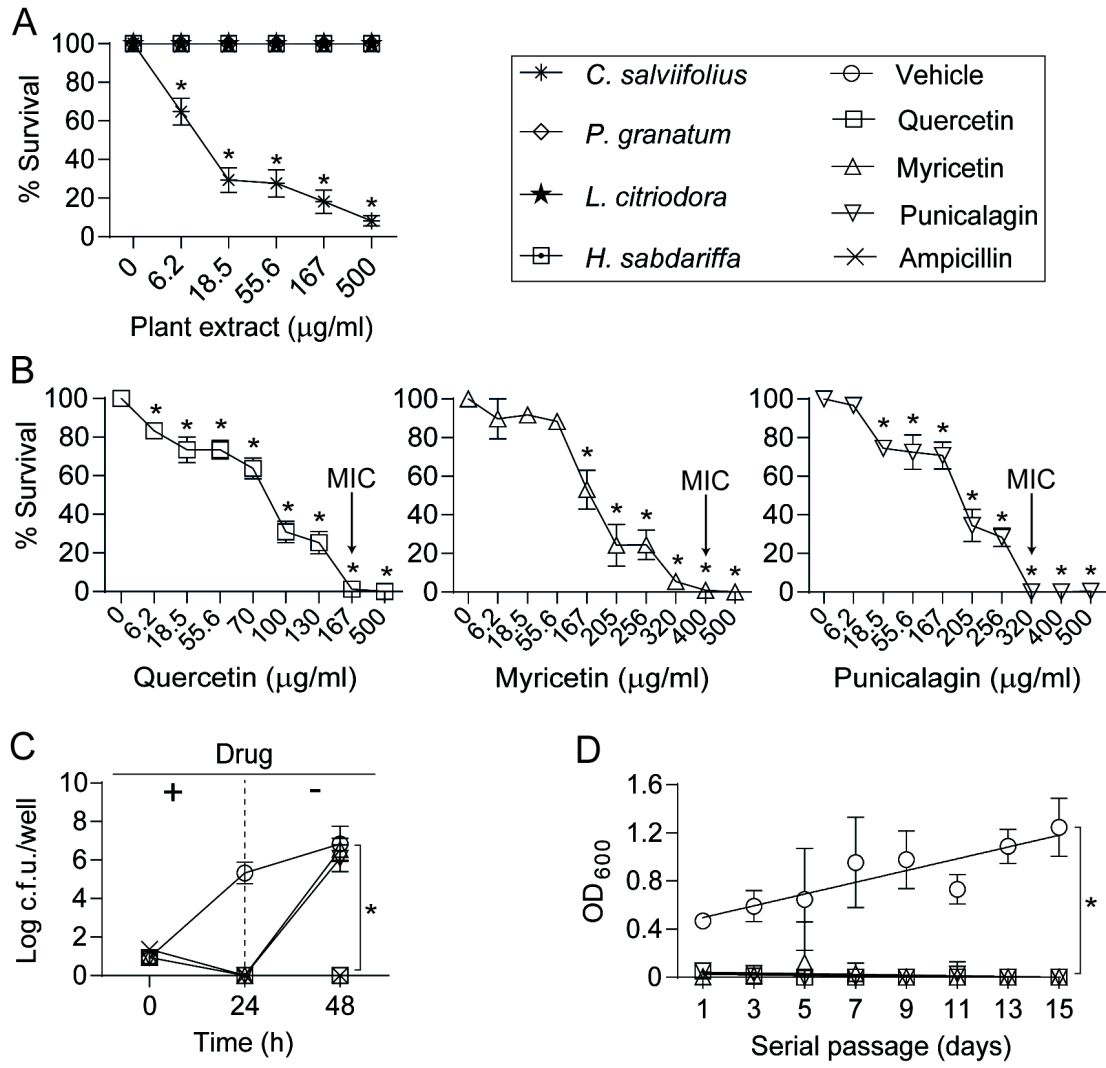

Figure 1. Antimicrobial effect of plant extracts and pure polyphenols on H. influenzae. (A) NTHi375 strain is susceptible to Cistus salviifolius extract in a dose-dependent manner ( $\left.{ }^{*} p<0.001\right)$. Results are shown as the survival percentage (mean \pm SEM); (B) Polyphenols present in the C. salviifolius extract, quercetin $\left({ }^{*} p<0.001\right)$, myricetin $\left({ }^{*} p<0.0001\right)$ and punicalagin $\left({ }^{*} p<0.0001\right)$, reduced NTHi375 survival in a dose-dependent manner. Survival percentage (mean \pm SEM) is shown; (C) Quercetin has a bactericidal effect, and myricetin and punicalagin have a bacteriostatic effect on NTHi375, when comparing bacterial counts (log c.f.u./well, mean \pm SD) after incubation with- and without polyphenol inhibitory concentrations. At $24 \mathrm{~h}$, only bacteria incubated with vehicle solution rendered counts, when compared with ampicillin (Amp)-treated cultures $\left.{ }^{*} p<0.0001\right)$. After polyphenol replacement by sBHI, $48 \mathrm{~h}$ bacterial cultures previously incubated with punicalagin or myricetin rendered significant counts, when compared with quercetin and Amp treated cultures $\left({ }^{*} p<0.0001\right)$; (D) NTHi375 did not grow after 15 daily serial passages in the presence of polyphenol (quercetin, myricetin or punicalagin) subinhibitory concentrations. Data are shown as $\mathrm{OD}_{600}$ (mean $\pm \mathrm{SD}$ ) in every passage $\left({ }^{*} p<0.0005\right)$. Statistical comparisons of the means were performed with two-way ANOVA (A and C) or one-way ANOVA (B and D), and Dunnett's multiple comparisons test.

When quercetin, myricetin, and punicalagin were combined at different proportion and tested against NTHi375 by the checkerboard method, antagonism or synergy effects were not detected. The same result was obtained when the three polyphenols were independently combined with the antibiotics azithromycin (Azm) or ampicillin (Amp). Results in Table 1 show the MIC \pm SD for each compound separately, the MIC \pm SD of the combinations tested, calculated $\Sigma F I C \pm S D$, and their interpretation. 
Table 1. The checkboard method for NTHi strain 375, when combining polyphenol:polyphenol or polyphenol:antibiotic molecules (mean $\pm \mathrm{SD}$ ).

\begin{tabular}{|c|c|c|c|c|c|c|c|}
\hline \multicolumn{2}{|c|}{ Combination $(\mathrm{A}+\mathrm{B})$} & \multirow{2}{*}{$\begin{array}{c}\mathrm{MIC}_{\mathrm{A}} \\
(\mu \mathrm{g} / \mathrm{mL})\end{array}$} & \multirow{2}{*}{$\begin{array}{l}\mathrm{MIC}_{\mathrm{A}}(\mathrm{A}+\mathrm{B} \\
\text { Combination) }\end{array}$} & \multirow{2}{*}{$\begin{array}{c}\mathrm{MIC}_{\mathrm{B}} \\
(\mu \mathrm{g} / \mathrm{mL})\end{array}$} & \multirow{2}{*}{$\begin{array}{c}\mathrm{MIC}_{\mathrm{B}}(\mathrm{A}+\mathrm{B} \\
\text { Combination) }\end{array}$} & \multirow{2}{*}{$\Sigma F I C$} & \multirow{2}{*}{ Result } \\
\hline A & B & & & & & & \\
\hline Quercetin & Punicalagin & 167 & 83.5 & 320 & 160 & 1 & Indiferent \\
\hline Quercetin & Myricetin & $250 \pm 118$ & 167 & 800 & $125 \pm 106$ & $0.91 \pm 0.22$ & Indiferent \\
\hline Punicalagin & Myricetin & 320 & 80 & 800 & 800 & 1.25 & Indiferent \\
\hline Quercetin & Azm & 167 & $125.25 \pm 59$ & $1.5 \pm 0.71$ & $1.5 \pm 0.71$ & $2 \pm 1.41$ & Indiferent \\
\hline Myricetin & Azm & 400 & 12.5 & $1.5 \pm 0.71$ & 2 & $1.53 \pm 0.71$ & Indiferent \\
\hline Punicalagin & Azm & 320 & $50 \pm 42.4$ & 2 & $1.5 \pm 0.71$ & $0.91 \pm 0.49$ & Indiferent \\
\hline Quercetin & Amp & $125 \pm 59$ & 10.45 & 1 & $1.5 \pm 0.71$ & $1.6 \pm 0.75$ & Indiferent \\
\hline Myricetin & Amp & 400 & 800 & 1 & 2 & 4 & Indiferent \\
\hline Punicalagin & Amp & 320 & 640 & 1 & 0.13 & 2.13 & Indiferent \\
\hline
\end{tabular}

We next assessed the ability of NTHi to become resistant to quercetin, myricetin, or punicalagin through serial independent passage of strain NTHi375 in sBHI broth containing subinhibitory concentrations $(<\mathrm{MIC})$ of each polyphenol, and using Amp and vehicle solution as controls. After 15 consecutive overnight passages, no growth was detected (Figure 1D).

In summary, quercetin presented a bactericidal activity and, under the conditions tested, it did not seem to induce resistance of NTHi375. Based on these observations, quercetin was shortlisted to next assess its modulatory effect on the NTHi-host airway interplay. NTHi375 was used for this purpose, given that it has been previously used in host-pathogen interaction studies [42,47-49].

\subsection{Quercetin Modulates NTHi Infection of Cultured Airway Epithelial Cells}

Quercetin is known to modulate eukaryotic cell signaling by inhibiting Akt phosphorylation [50] and phosphodiesterase 4 (PDE4) [51]. Akt phosphorylation has been reported to facilitate- and increased intracellular cAMP to reduce NTHi epithelial invasion, respectively [39,41,52]. Based on previously known quercetin modulatory effects, we hypothesized that host cell treatment with this polyphenol may reduce NTHi epithelial infection. First, quercetin effect on bacterial viability was titrated in EBSS medium aiming to mimic cultured epithelial cell infection conditions (see Materials and Methods section). A significant decrease on NTHi375 bacterial viability was observed at quercetin concentrations as low as $3 \mu \mathrm{g} / \mathrm{mL}$ (Figure 2A). Such quercetin concentrations did not cause a cytotoxic effect on A549 cells upon $6 \mathrm{~h}$ cell exposure (data not shown). Based on these observations, cells were pretreated with EBSS containing quercetin for $4 \mathrm{~h}$, which was replaced by EBSS medium without drug prior infection. Exposure to increasing doses of quercetin reduced NTHi375 epithelial adhesion and invasion rates in a dose-dependent manner. Adhesion data showed a clear but non-significant trend, and invasion data showed a significant reduction upon cell pretreatment with quercetin $60 \mu \mathrm{g} / \mathrm{mL}$ (Figure 2B,C). We also monitored quercetin effect on Akt phosphorylation during NTHi infection. Quercetin was shown to inhibit Akt phosphorylation under the conditions tested (Figure 2E), which may at least partially contribute explaining the observed diminished bacterial cell invasion.

Quercetin eukaryotic cell permeation may occur by a passive diffusion mechanism [53]. Given that antimicrobial penetrating epithelial cells can reduce intracellular NTHi viability [33], we asked if quercetin could reduce the viability of internalized bacteria. To do so, A549 cell infection with NTHi375 was performed in culture medium without drug supplementation, followed by subsequent incubation in fresh medium supplemented with gentamicin to kill extracellular bacteria, and with vehicle solution or quercetin, 30 or $60 \mu \mathrm{g} / \mathrm{mL}$. Under these conditions, quercetin did not reduce the number of intracellular bacteria (Figure 2D).

Together, these results show that quercetin sub-inhibitory concentrations modulate NTHi375 airway epithelial cell infection, and quercetin-driven inactivation of Akt may play a role in such interference. Under the conditions tested, quercetin does not modify already internalized bacterial numbers. 
A
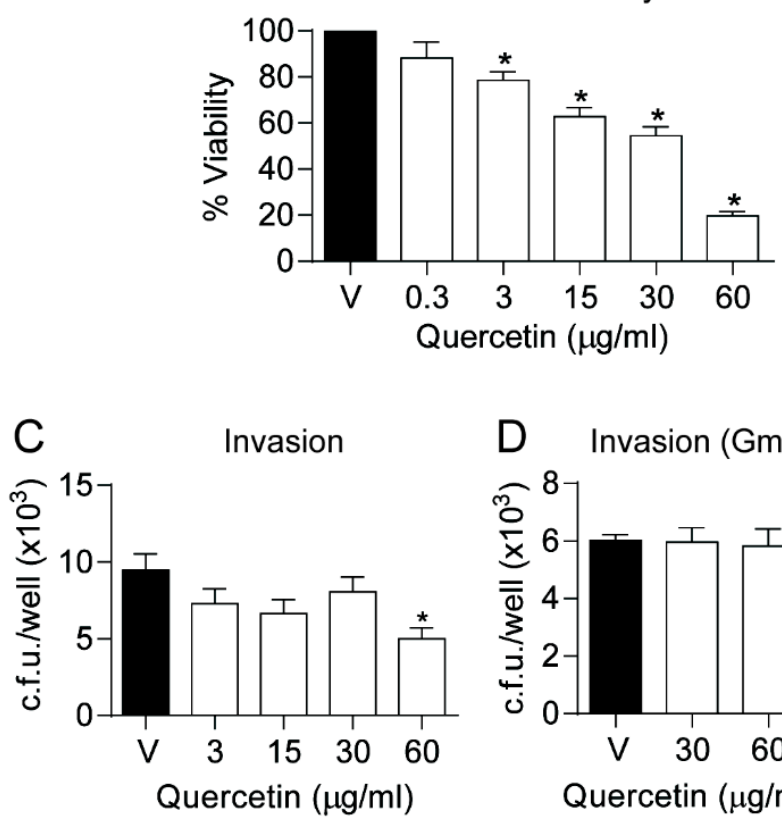

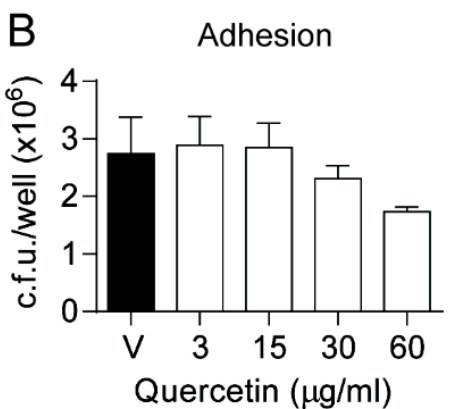

E Time post-infection ( $\mathrm{min}$ )

Figure 2. Quercetin modulates $H$. influenzae airway epithelial cell infection. (A) NTHi375 viability was tested by simulating host cell infection conditions $\left(2 \mathrm{~h}\right.$ at $37^{\circ} \mathrm{C}$ in EBSS medium, in the absence $(\mathrm{V}) /$ presence of quercetin). Quercetin reduced $\left({ }^{*} p<0.0001\right)$ bacterial viability (mean $\left.\pm \mathrm{SEM}\right)$ in a dose-dependent manner. Based on these results, cell infection assays shown in panels $\mathbf{B}, \mathbf{C}$ and $\mathbf{E}$ were performed by cell pretreatment with quercetin for $4 \mathrm{~h}$, and drug removal prior infection. Controls (V): cells did not receive quercetin, but did receive vehicle solution, i.e., DMSO; (B) Adhesion assays did not render significant differences, despite showing a reproducible trend toward lower adherent bacterial counts; (C) A significant reduction of NTHi375 epithelial invasion was observed in cells pretreated with quercetin $60 \mu \mathrm{g} / \mathrm{mL}\left({ }^{*} p<0.01\right)$; (D) Quercetin effect on intracellular NTHi375. A549 cells were infected and quercetin 30 or $60 \mu \mathrm{g} / \mathrm{mL}$ was added during cell incubation with gentamicin (Gm). Quercetin did not reduce the number of intracellular bacteria. Results are shown as c.f.u./well (mean \pm SEM). Statistical comparisons of the means were performed with one-way ANOVA and Dunnett's multiple comparisons test; (E) Quercetin impairs Akt phosphorylation during NTHi infection. Quercetin-treated cells showed no Akt activation upon infection, opposite to DMSO-treated cells showing time-dependent Akt phosphorylation. A representative western-blot showing P-Akt (activated form) and total Akt (loading control) is shown.

\subsection{Quercetin Lowers Proinflammatory Gene Expression by Epithelial Cells Infected with H. influenzae}

Quercetin has shown to reduce proinflammatory cytokine production in Vibrio cholerae infected intestinal epithelial cells [54], and in Streptococcus suis infected macrophages [55]. To determine if quercetin modulates the expression of genes encoding proinflammatory cytokines in human airway epithelial cells followed by NTHi infection, A549 cells were pretreated with quercetin. To maintain the polyphenol at the onset of the infectious inflammatory stimulus without jeopardizing bacterial viability, we assessed gene expression by cells incubated with heat killed (HK) bacteria. Under these conditions, expression of the il-8, cxcl-1 and il-6 genes was stimulated, compared to control uninfected cells, and such stimulation was significantly reduced when cells were treated with quercetin in a dose-dependent manner (Figure 3A-C). 

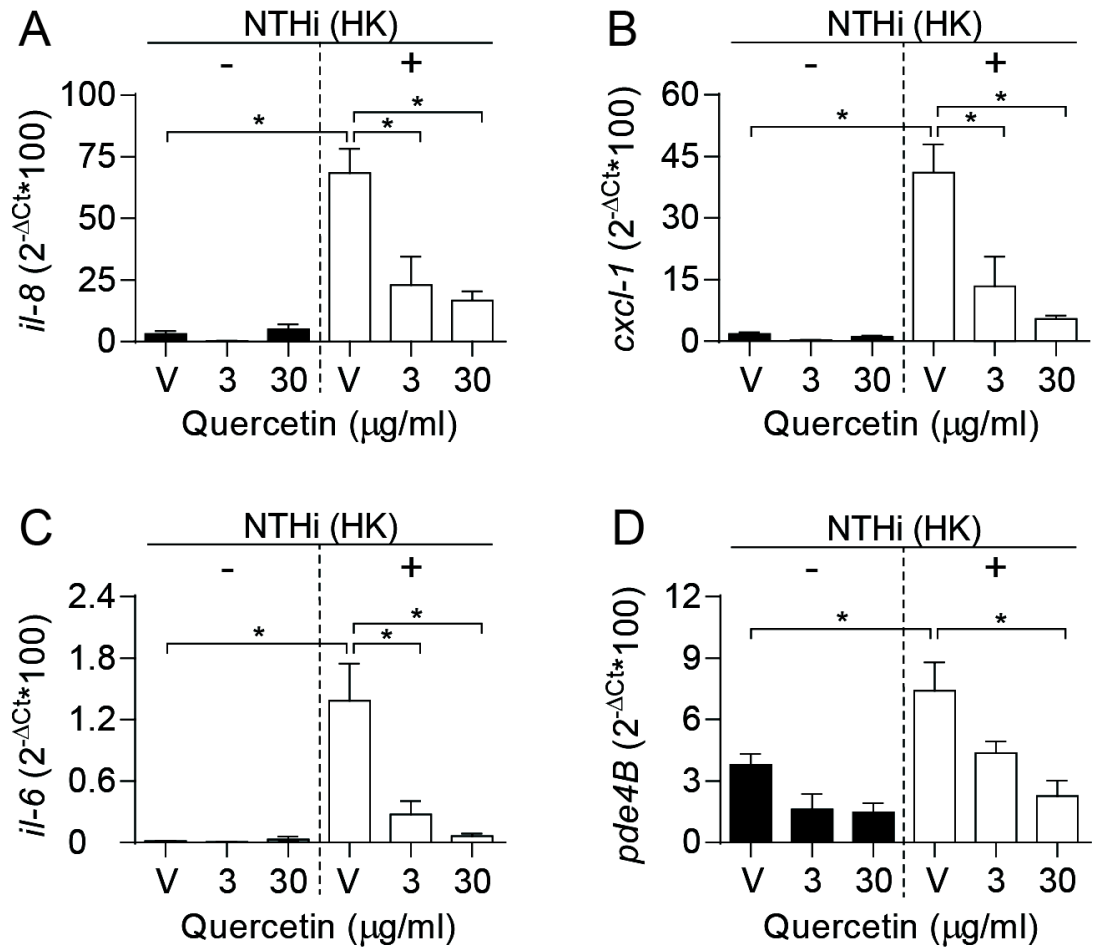

Figure 3. Quercetin has an anti-inflammatory effect on NTHi-infected airway epithelial cells. A549 cells were pretreated with quercetin or DMSO (vehicle solution) for $4 \mathrm{~h}$; next, heat killed (HK) bacteria were used as an inflammatory stimulus (NTHi HK) for 2 additional hours. Black bars, non-infected; white bars, infected cells. V refers to cells exposed to vehicle solution. To monitor gene expression, relative quantity of human il-8 (A), cxcl-1 (B), il-6 (C) and $p d e 4 b$ (D) mRNA was measured by qRT-PCR. In all cases, gene expression was significantly increased upon infection of control untreated cells $\left({ }^{*} p\right.$ $<0.0001$ for A, B and C; ${ }^{*} p<0.05$ for D). Quercetin reduced gene expression in a dose-dependent manner. Quercetin $3 \mu \mathrm{g} / \mathrm{mL}$ significantly decreased il-8 (A, $\left.{ }^{*} p<0.001\right), c x c l-1$ (B, $\left.{ }^{*} p<0.005\right)$ and il-6 $\left(C^{*}{ }^{*} p<0.05\right)$ expression level. Quercetin $30 \mu \mathrm{g} / \mathrm{mL}$ was effective by reducing the expression of the four markers being tested $\left({ }^{*} p<0.0001\right.$ for $\mathbf{A}$ and $\mathbf{B} ;{ }^{*} p<0.01$ for $\mathbf{C}$ and $\left.\mathbf{D}\right)$. Results are shown as the relative quantity of each gene (mean \pm SEM). Statistical comparisons of the means were performed with one-way ANOVA and Sidak's multiple comparisons test (A, B, C and D).

Conversely, therapeutic inhibition of PDE4 has a variety of known anti-inflammatory effects beneficial in the treatment of COPD [56]. Given that quercetin is a naturally occurring selective PDE4 inhibitor [51], and that NTHi airway epithelial infection stimulates differential expression for several PDEs including PDE4B (the major PDE isoform expressed in lung) [52], the question arises as to if quercetin's anti-inflammatory effect on NTHi-infected cells could also be mediated by modulating $p d e 4 b$ gene expression. As shown in Figure 3D, pde4b gene expression was increased in cells incubated with HK bacteria for $2 \mathrm{~h}$, when compared to control uninfected cells, and quercetin treatment significantly lowered $p d e 4 b$ gene expression in a dose-dependent manner.

In conclusion, these results show quercetin likely anti-inflammatory effects when maintained at the onset of the infectious inflammatory stimulus, as a means of lowering $i l-8, c x c l-1, i l-6$, and $p d e 4 b$ gene expression.

\subsection{Antimicrobial and Anti-inflammatory Effects of Quercetin Administration on Mouse Lung Infection with $\mathrm{NTHi}$}

Next, we sought to determine the effect of quercetin oral administration in vivo, by NTHi respiratory infection of mice with previously induced lung emphysema. We used a regimen of oral quercetin $(60 \mathrm{mg} / \mathrm{kg})$ consisting of daily administrations during 8 days prior to infection and three 
administrations at 6,12 and 23 hpi (Figure 4A). We observed a moderate reduction in NTHi counts following treatment with quercetin, with a non-statistically significant but reproducible trend to be lower in quercetin-treated than in control untreated animals (Figure 4B). We asked if such moderate reduction in NTHi counts following quercetin administration may relate to impaired phagocytosis by alveolar macrophages. However, MH-S cell exposure to quercetin did not modify NTHi uptake, despite showing a significant anti-inflammatory effect by the means of reducing the expression of the tnfo gene in cells incubated with HK bacteria (Figure S2).

A
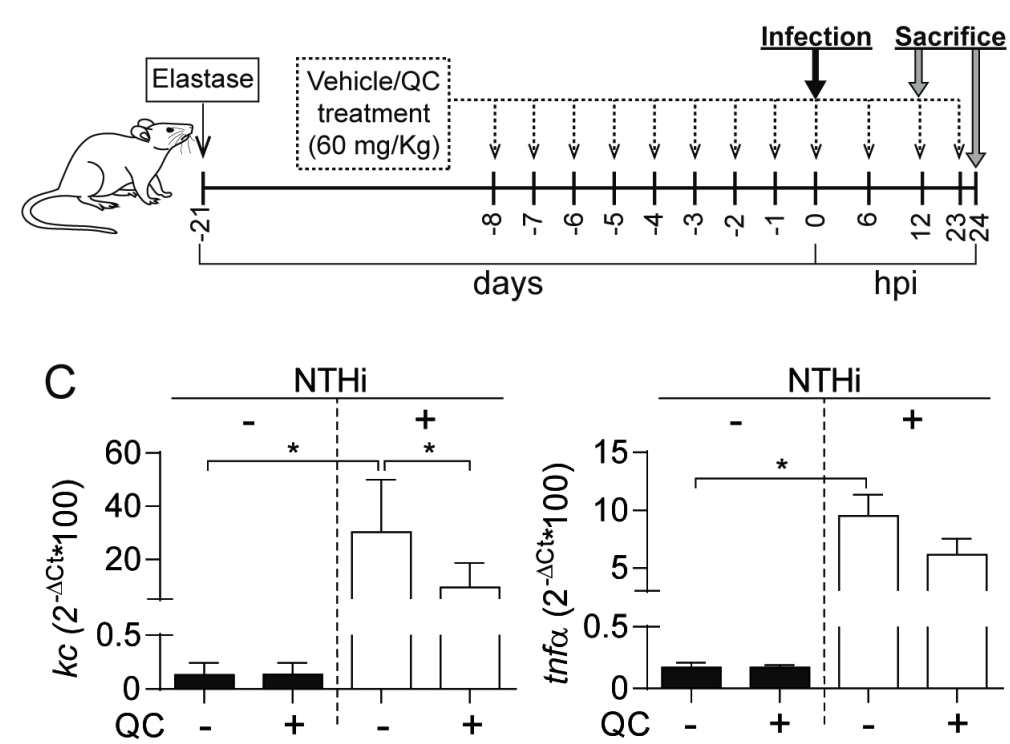

B
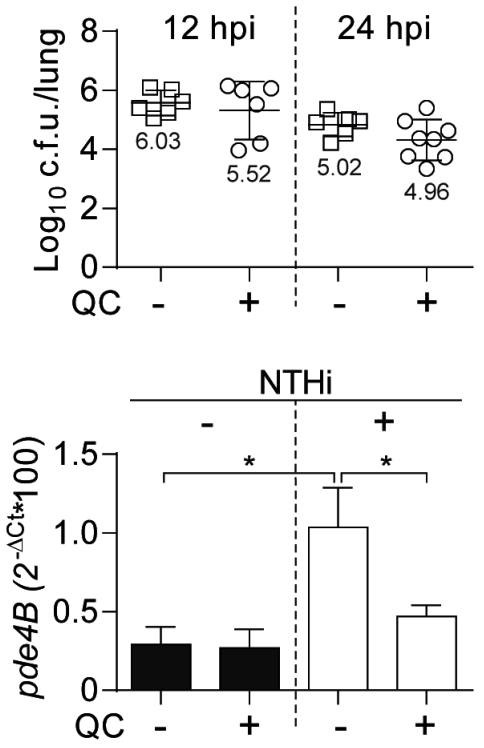

Figure 4. Effect of quercetin administration on bacterial loads and proinflammatory markers in emphysema mice infected by NTHi. (A) Experimental design: lung emphysema was induced by intratracheal instillation of pancreatic porcine elastase. Animals were infected intranasally with $\sim 10^{8}$ c.f.u./mouse. Quercetin (QC, $60 \mathrm{mg} / \mathrm{kg} / \mathrm{dose}$ ) was administered orally. Controls: animals were administered vehicle solution but did not receive quercetin; (B) Bacterial counts were determined at 12 and 24 hpi for lung ( $\log _{10}$ c.f.u./lung) samples; (C) Relative quantities of mouse $k c$, tnf $\alpha$ and $p d e 4 b$ mRNA were measured by RT-qPCR analysis on lung samples corresponding to non-infected untreated, non-infected quercetin treated, NTHi infected untreated, and NTHi infected quercetin treated groups. At $12 \mathrm{hpi}$, expression of the three genes was increased in infected compared to uninfected mice ${ }^{*} p<$ 0.005 for $k c ;{ }^{*} p<0.0005$ for $t n f \alpha ;{ }^{*} p<0.05$ for $\left.p d e 4 b\right)$, and those genes expression was lower in NTHi infected quercetin treated than in untreated mice $\left(k c,{ }^{*} p<0.05 ; p d e 4 b, * p<0.05\right)$. Results are shown as mean \pm SD. Statistical comparisons of the means were performed with one-way ANOVA and Sidak's multiple comparisons test.

Next, we analyzed NTHi-induced expression of $k c$ and $t n f \alpha$ proinflammatory mediators in mice lung tissue euthanized at $12 \mathrm{hpi}$, which rendered higher numbers than those obtained for control uninfected animals. In turn, treatment with quercetin decreased NTHi-induced expression of $k c$ and tnf $\alpha$ in infected mice lung tissue. The $p d e 4 b$ gene expression was also increased in lung tissue of NTHi-infected mice, compared to control non-infected animals, and quercetin treatment decreased NTHi-induced expression of $p d e 4 b$ in infected lung tissue. No differences in terms of $k c, \operatorname{tnf\alpha }$, or $p d e 4 b$ gene expression were observed in quercetin treated and control untreated non-infected animals (Figure 4C).

In summary, these results show that quercetin $60 \mathrm{mg} / \mathrm{kg}$ moderately reduces bacterial load, and lowers the expression of whole-lung inflammatory markers. 


\subsection{Quercetin Antimicrobial Protective Effect on Zebrafish Systemic Infection with NTHi}

Lastly, a quercetin acute toxicity assay was performed in zebrafish embryos following the fish embryo acute toxicity (FET) test. Results showed that the highest quercetin non-toxic dose was $7 \mu \mathrm{g} / \mathrm{mL}$ (data not shown). We then performed a quercetin assay in adult zebrafish, following a previously established sepsis model system by intraperitoneal NTHi infection [30]. We assessed quercetin antimicrobial effect on NTHi375 infected zebrafish by using a therapeutic regimen of intraperitoneal quercetin $(0.3 \mathrm{mg} / \mathrm{g})$ consisting of two administrations at 29 and $53 \mathrm{hpi}$. Survival rate for quercetin-treated and control untreated groups was monitored up to 5 days post-infection. Mortality rate in quercetin-treated infected zebrafish was significantly lower than in infected animals receiving vehicle solution (Figure 5). This model system rendered significant quercetin-mediated increased survival upon zebrafish NTHi infection.
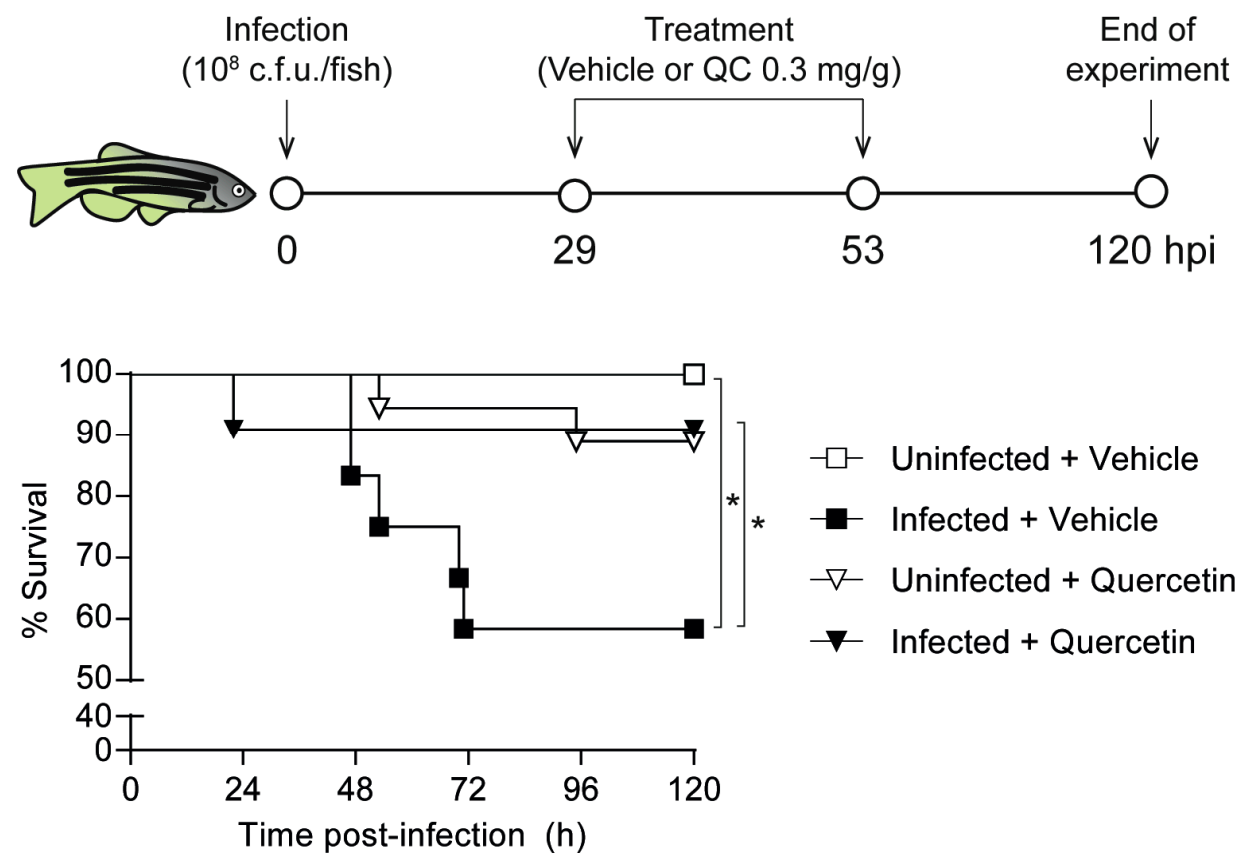

Figure 5. Effect of quercetin administration on zebrafish infected by NTHi. Zebrafish were infected intraperitoneally with NTHi375, $10^{8}$ c.f.u./fish. When necessary, quercetin $0.3 \mathrm{mg} / \mathrm{g} /$ dose was administered intraperitoneally at 29 and 53 hpi. Non-infected groups were administered perfusion solution-DMSO (1:1) (white square) or quercetin (white triangle); infected groups were administered perfusion solution-DMSO (1:1) (black square) or quercetin (black triangle). Survival rate is reported as percentage (mean \pm SD) of adult individuals survival up to $120 \mathrm{hpi}$. Survival of NTHi infected zebrafish was significantly higher in quercetin treated than in untreated animals $\left({ }^{*} p<0.05\right)$. To draw and analyze the Kaplan-Meier survival curve, a Log-rank (Mantel-cox) test was used $*^{*} p<0.05$ ). Statistical comparisons between survival rates after $120 \mathrm{~h}$ were performed with one-way ANOVA and Sidak's multiple comparisons test.

\section{Discussion}

Chronic inflammation and NTHi infectious exacerbations are two major pathophysiological traits of COPD progression. Therapeutics targeting both infection and overactive inflammation at the COPD airway are of interest, and even more so when clinical evidence supports corticosteroid therapeutic failure not only associated with increased risk for pneumonia, but also to oxidative stress- and H. influenzae-mediated insensitivity [10-13,57]. Benefits of drugs with dual antimicrobial/anti-inflammatory properties have been mostly exploited for the macrolide antibiotic azithromycin, whose long-term low-dose use to prevent and/or manage COPD exacerbations may be beneficial, but could also increase the rate of macrolide resistance and cause adverse effects [58]. 
In the present study, our search of plant xenohormetic molecules effective against NTHi led us to focus on quercetin, a flavonoid ubiquitously present in vegetables, fruits, tea, and wine, claimed to exert beneficial effects linked to being one of the most prominent dietary antioxidants, with high accumulation observed in rat lung tissue [59]. Protective effects of quercetin in lung lesions have been reported on lipopolysaccharide-induced acute lung injury and elastase-induced emphysema murine model systems [22,60,61]. Moreover, quercetin seems to restore corticosteroid sensitivity in cells from COPD patients by activation of the adenosine monophosphate-activated protein kinase (AMPK) [62], and a community clinical trial showed a reduction of upper respiratory tract infection total sick days and severity in middle age and older subjects ingesting $1000 \mathrm{mg}$ quercetin/day for 12 weeks [63]. Quercetin antimicrobial effect has been previously reported [64-66] but, to our knowledge, this is the first study assessing its antimicrobial activity against $H$. influenzae.

From the antimicrobial perspective, quercetin showed a bactericidal effect on $H$. influenzae, and growth was not detected on a serial passage assay, suggesting that this pathogen does not develop resistance. However, we did not observe synergism, polyphenol-polyphenol or polyphenol-antibiotic, different to previously reported synergistic activities against Pseudomonas aeruginosa, Acinetobacter baumannii or Staphylococcus aureus [28,64]. From the immunomodulatory perspective, quercetin reduced the expression of key proinflammatory markers in both epithelial cells and alveolar macrophages upon NTHi bacterial infection. Such an anti-inflammatory effect could also be seen in vivo upon pulmonary infection of emphysema mice, although the quercetin impact on NTHi bacterial counts was only moderate in this experimental setting. In vivo treatment of mouse infection with quercetin, by using regimens ranging from 25 to $150 \mathrm{mg} / \mathrm{kg}$, has reported fairly variable results, from Streptococcus suis virulence reduction and suppression of lethal shock upon Salmonella typhimurium infection [55,67], to a moderate decrease in Helicobacter pylori counts [68], no effect on bacterial counts in a mouse model of periodontitis by Aggregatibacter actinomycetemcomitants [69], or even increased Chlamydia pneumoniae counts in murine lungs [70]. Here, quercetin administration showed a non-significant trend towards reducing NTHi bacterial counts in mouse lung homogeneates, and a clearer protective effect on the zebrafish sepsis model system. Our previous study showed that administration of resveratrol reduced bacterial counts in both mice and zebrafish model systems, and it did not modify expression of the $p d e 4 b$ gene [30], whose inactivation is a known anti-inflammatory procedure in COPD therapeutics, and could indeed be observed upon quercetin treatment in both cultured epithelial cells and murine lung homogenates upon NTHi infection.

Thus, the usefulness of modulating COPD immune responses by using antimicrobial xenohormetic molecules highlights that the therapeutic benefit of molecules with dual antimicrobial and immunomodulatory properties is likely to require the fine-tuned balance of both effects. A delicate balance between immunity and inflammation is therefore required for making it possible to fight pathogens effectively while limiting inflammation that might be damaging to the host. We hereby put forward the notion that such bilateral (bacterial burden and host immunomodulation) analysis should always be performed when exploring anti-inflammatory molecules to achieve unbiased information. In fact, the non-antimicrobial corticosteroid dexamethasone attenuates inflammation after NTHi challenge, but also increases bacterial burden [71], and the effect of the polyphenolic immunomodulator curcumin on NTHi bacterial loads is unknown [72,73] and should probably be revisited.

Finally, an investigation of plant extract or pure polyphenol administration route, body distribution, bioavailability, pharmacokinetics, and synergistic effects with conventional antimicrobials in vivo is necessary. When orally administering the C. salviifolius extract, punicalagins will be poorly bioavailable, and quercetin, upon absorption, will be subjected to different types of metabolism with quercetin-3-O- $\beta$-D-glucuronide and quercetin aglycone as the main pharmacologically active metabolites in plasma, in a similar fashion to pure quercetin oral administration [74,75].

In conclusion, we present here the therapeutic potential of polyphenol containing plant extracts, and of quercetin in particular, against NTHi infection. Further work will help to better define 
polyphenol lead candidates of potential use in counteracting chronic airway diseases undergoing infectious exacerbations.

Supplementary Materials: The following are available online at http://www.mdpi.com/2218-273X/9/12/891/s1, Figure S1: Antimicrobial effect of plant extracts and pure polyphenols on $H$. influenzae RdKW20, Figure S2: Quercetin has an anti-inflammatory effect on NTHi-infected alveolar macrophages, Table S1: Primers used for qRT-PCR in this study, Table S2: Minimal inhibitory concentration (MIC) of quercetin, myricetin and punicalagin against NTHi clinical isolates, measured by microdilution $(\mu \mathrm{g} / \mathrm{mL})$.

Author Contributions: Conceptualization, A.F.-C., B.E., E.B.-C., J.G.; Methodology, A.F.-C., B.E., L.C., R.D.-M., E.B.-C., J.G.; Formal Analysis, A.F.-C., B.E., R.D.-M., J.G.; Investigation, A.F.-C., B.E., J.G.; Resources, V.M., E.B.-C.; Data Curation, A.F.-C., B.E., R.D.-M., J.G.; Writing-Original Draft Preparation, A.F.-C., B.E., J.G.; Writing-Review \& Editing, all authors; Supervision, J.G.; Project Administration, J.G.; Funding Acquisition, M.M., C.O.d.S., J.L., V.M., J.G.

Funding: This work has been funded by grants from MINECO SAF2015-66520-R and RTI2018-096369-B-I00, PI011 from Economical Development Department, Regional Navarra Govern, Spain, and 31/2015 from SEPAR to J.G., by grant from MINECO DRTI2018-094494-B-C22 (MCIU/AEI/FEDER, UE) to C.O.S., by grants from MINECO AGL2015-67995-C3-1-R and RTI2018-096724-B-C21, PROMETEO/2016/006 from Generalitat Valenciana, and CIBERobn (CB12/03/30038) to V.M, by grant 03/2016 from Health Department, Regional Navarra Govern, Spain to J.G., C.O.S. and J.L, and by grant CIBERES (CB06/06/1102) to M.M. CIBER is an initiative from Instituto de Salud Carlos III (ISCIII), Madrid, Spain.

Conflicts of Interest: The authors declare no conflict of interest.

\section{References}

1. Mannino, D.M.; Buist, A.S. Global burden of COPD: Risk factors, prevalence, and future trends. Lancet 2007, 370, 765-773. [CrossRef]

2. Hogg, J.C. Pathophysiology of airflow limitation in chronic obstructive pulmonary disease. Lancet 2004, 364, 709-721. [CrossRef]

3. Hogg, J.C.; Chu, F.; Utokaparch, S.; Woods, R.; Elliott, W.M.; Buzatu, L.; Cherniack, R.M.; Rogers, R.M.; Sciurba, F.C.; Coxson, H.O.; et al. The nature of small-airway obstruction in chronic obstructive pulmonary disease. N. Engl. J. Med. 2004, 350, 2645-2653. [CrossRef] [PubMed]

4. Rangelov, K.; Sethi, S. Role of infections. Clin. Chest. Med. 2014, 35, 87-100. [CrossRef]

5. Ahearn, C.P.; Gallo, M.C.; Murphy, T.F. Insights on persistent airway infection by non-typeable Haemophilus influenzae in chronic obstructive pulmonary disease. Pathog. Dis. 2017, 75. [CrossRef]

6. Duell, B.L.; Su, Y.C.; Riesbeck, K. Host-pathogen interactions of nontypeable Haemophilus influenzae: From commensal to pathogen. FEBS Lett. 2016, 590, 3840-3853. [CrossRef]

7. Aaron, S.D.; Angel, J.B.; Lunau, M.; Wright, K.; Fex, C.; Le Saux, N.; Dales, R.E. Granulocyte inflammatory markers and airway infection during acute exacerbation of chronic obstructive pulmonary disease. Am. J. Respir. Crit. Care Med. 2001, 163, 349-355. [CrossRef]

8. Papi, A.; Bellettato, C.M.; Braccioni, F.; Romagnoli, M.; Casolari, P.; Caramori, G.; Fabbri, L.M.; Johnston, S.L. Infections and airway inflammation in chronic obstructive pulmonary disease severe exacerbations. Am. J. Respir. Crit. Care Med. 2006, 173, 1114-1121. [CrossRef]

9. Sethi, S.; Muscarella, K.; Evans, N.; Klingman, K.L.; Grant, B.J.; Murphy, T.F. Airway inflammation and etiology of acute exacerbations of chronic bronchitis. Chest 2000, 118, 1557-1565. [CrossRef]

10. Izquierdo, J.L.; Cosio, B.G. The dose of inhaled corticosteroids in patients with COPD: When less is better. Int. J. Chron. Obstruct. Pulmon. Dis. 2018, 13, 3539-3547. [CrossRef]

11. Liapikou, A.; Cilloniz, C.; Torres, A. Drugs that increase the risk of community-acquired pneumonia: A narrative review. Expert Opin. Drug Saf. 2018, 17, 991-1003. [CrossRef] [PubMed]

12. Restrepo, M.I.; Sibila, O.; Anzueto, A. Pneumonia in patients with chronic obstructive pulmonary disease. Tuberc. Respir. Dis. (Seoul) 2018, 81, 187-197. [CrossRef] [PubMed]

13. Jiang, Z.; Zhu, L. Update on molecular mechanisms of corticosteroid resistance in chronic obstructive pulmonary disease. Pulm. Pharmacol. Ther. 2016, 37, 1-8. [CrossRef] [PubMed]

14. Ramos, F.L.; Criner, G.J. Use of long-term macrolide therapy in chronic obstructive pulmonary disease. Curr. Opin. Pulm. Med. 2014, 20, 153-158. [CrossRef] [PubMed]

15. Huckle, A.W.; Fairclough, L.C.; Todd, I. Prophylactic antibiotic use in COPD and the potential anti-inflammatory activities of antibiotics. Respir. Care 2018, 63, 609-619. [CrossRef] [PubMed] 
16. Taylor, S.P.; Sellers, E.; Taylor, B.T. Azithromycin for the prevention of COPD exacerbations: The good, bad, and ugly. Am. J. Med. 2015, 128, 1362.e1-1362.e6. [CrossRef]

17. Howitz, K.T.; Sinclair, D.A. Xenohormesis: Sensing the chemical cues of other species. Cell 2008, 133, 387-391. [CrossRef]

18. Arts, I.C.; Hollman, P.C. Polyphenols and disease risk in epidemiologic studies. Am. J. Clin. Nutr. 2005, 81, 317S-325S. [CrossRef]

19. Heim, K.E.; Tagliaferro, A.R.; Bobilya, D.J. Flavonoid antioxidants: Chemistry, metabolism and structure-activity relationships. J. Nutr. Biochem. 2002, 13, 572-584. [CrossRef]

20. Tabak, C.; Arts, I.C.; Smit, H.A.; Heederik, D.; Kromhout, D. Chronic obstructive pulmonary disease and intake of catechins, flavonols, and flavones: The MORGEN Study. Am. J. Respir. Crit. Care Med. 2001, 164, 61-64. [CrossRef]

21. Lee, S.U.; Ryu, H.W.; Lee, S.; Shin, I.S.; Choi, J.H.; Lee, J.W.; Lee, J.; Kim, M.O.; Lee, H.J.; Ahn, K.S.; et al. Lignans isolated from flower buds of Magnolia fargesii attenuate airway inflammation induced by cigarette smoke in vitro and in vivo. Front. Pharmacol. 2018, 9, 970. [CrossRef] [PubMed]

22. Ganesan, S.; Faris, A.N.; Comstock, A.T.; Chattoraj, S.S.; Chattoraj, A.; Burgess, J.R.; Curtis, J.L.; Martinez, F.J.; Zick, S.; Hershenson, M.B.; et al. Quercetin prevents progression of disease in elastase/LPS-exposed mice by negatively regulating MMP expression. Respir. Res. 2010, 11, 131. [CrossRef] [PubMed]

23. Suzuki, M.; Betsuyaku, T.; Ito, Y.; Nagai, K.; Odajima, N.; Moriyama, C.; Nasuhara, Y.; Nishimura, M. Curcumin attenuates elastase- and cigarette smoke-induced pulmonary emphysema in mice. Am. J. Physiol. Lung Cell. Mol. Physiol. 2009, 296, L614-L623. [CrossRef] [PubMed]

24. Daglia, M. Polyphenols as antimicrobial agents. Curr. Opin. Biotechnol. 2012, 23, 174-181. [CrossRef] [PubMed]

25. Guo, L.; Sun, Q.; Gong, S.; Bi, X.; Jiang, W.; Xue, W.; Fei, P. Antimicrobial activity and action approach of the olive oil polyphenol extract against Listeria monocytogenes. Front. Microbiol. 2019, 10, 1586. [CrossRef]

26. Mandal, S.M.; Dias, R.O.; Franco, O.L. Phenolic compounds in antimicrobial therapy. J. Med. Food 2017, 20, 1031-1038. [CrossRef]

27. Slobodnikova, L.; Fialova, S.; Rendekova, K.; Kovac, J.; Mucaji, P. Antibiofilm activity of plant polyphenols. Molecules 2016, 21, 1717. [CrossRef]

28. Tomas-Menor, L.; Barrajon-Catalan, E.; Segura-Carretero, A.; Marti, N.; Saura, D.; Menendez, J.A.; Joven, J.; Micol, V. The promiscuous and synergic molecular interaction of polyphenols in bactericidal activity: An opportunity to improve the performance of antibiotics? Phytother. Res. PTR 2015, 29, 466-473. [CrossRef]

29. Tomas-Menor, L.; Morales-Soto, A.; Barrajon-Catalan, E.; Roldan-Segura, C.; Segura-Carretero, A.; Micol, V. Correlation between the antibacterial activity and the composition of extracts derived from various Spanish Cistus species. Food Chem. Toxicol. 2013, 55, 313-322. [CrossRef]

30. Euba, B.; Lopez-Lopez, N.; Rodriguez-Arce, I.; Fernandez-Calvet, A.; Barberan, M.; Caturla, N.; Marti, S.; Diez-Martinez, R.; Garmendia, J. Resveratrol therapeutics combines both antimicrobial and immunomodulatory properties against respiratory infection by nontypeable Haemophilus influenzae. Sci. Rep. 2017, 7, 12860. [CrossRef]

31. Knobloch, J.; Sibbing, B.; Jungck, D.; Lin, Y.; Urban, K.; Stoelben, E.; Strauch, J.; Koch, A. Resveratrol impairs the release of steroid-resistant inflammatory cytokines from human airway smooth muscle cells in chronic obstructive pulmonary disease. J. Pharmacol. Exp. Ther. 2010, 335, 788-798. [CrossRef] [PubMed]

32. Wood, L.G.; Wark, P.A.; Garg, M.L. Antioxidant and anti-inflammatory effects of resveratrol in airway disease. Antioxid. Redox Signal. 2010, 13, 1535-1548. [CrossRef] [PubMed]

33. Euba, B.; Moleres, J.; Viadas, C.; Barberan, M.; Caballero, L.; Grillo, M.J.; Bengoechea, J.A.; de-Torres, J.P.; Linares, J.; Leiva, J.; et al. Relationship between azithromycin susceptibility and administration efficacy for nontypeable Haemophilus influenzae respiratory infection. Antimicrob. Agents Chemother. 2015, 59, 2700-2712. [CrossRef] [PubMed]

34. Mell, J.C.; Sinha, S.; Balashov, S.; Viadas, C.; Grassa, C.J.; Ehrlich, G.D.; Nislow, C.; Redfield, R.J.; Garmendia, J. Complete genome sequence of Haemophilus influenzae strain 375 from the middle ear of a pediatric patient with otitis media. Genome Announc. 2014, 2, e01245-14. [CrossRef] [PubMed]

35. Tyc, O.; Tomas-Menor, L.; Garbeva, P.; Barrajon-Catalan, E.; Micol, V. Validation of the AlamarBlue(R) assay as a fast screening method to determine the antimicrobial activity of botanical extracts. PLoS ONE 2016, 11, e0169090. [CrossRef] [PubMed] 
36. Herranz-López, M.; Losada-Echeberría, M.; Barrajón-Catalán, E. The multitarget activity of natural extracts on cancer: Synergy and xenohormesis. Medicines 2019, 6, 6. [CrossRef]

37. Schwalbe, R.; Steele-Moore, L.; Goodwin, A.C. Antimicrobial Susceptibility Testing Protocols, 1st ed.; CRC Press: Boca Raton, FL, USA, 2007; pp. 277-283.

38. Kubicek-Sutherland, J.Z.; Lofton, H.; Vestergaard, M.; Hjort, K.; Ingmer, H.; Andersson, D.I. Antimicrobial peptide exposure selects for Staphylococcus aureus resistance to human defence peptides. J. Antimicrob. Chemother. 2017, 72, 115-127. [CrossRef]

39. Morey, P.; Cano, V.; Marti-Lliteras, P.; Lopez-Gomez, A.; Regueiro, V.; Saus, C.; Bengoechea, J.A.; Garmendia, J. Evidence for a non-replicative intracellular stage of nontypeable Haemophilus influenzae in epithelial cells. Microbiology 2011, 157, 234-250. [CrossRef]

40. Marti-Lliteras, P.; Regueiro, V.; Morey, P.; Hood, D.W.; Saus, C.; Sauleda, J.; Agusti, A.G.; Bengoechea, J.A.; Garmendia, J. Nontypeable Haemophilus influenzae clearance by alveolar macrophages is impaired by exposure to cigarette smoke. Infect. Immun. 2009, 77, 4232-4242. [CrossRef]

41. López-Gómez, A.; Cano, V.; Moranta, D.; Morey, P.; del Portillo, F.; Bengoechea, J.A.; Garmendia, J. Host cell kinases, $\alpha 5$ and $\beta 1$ integrins, and Rac1 signalling on the microtubule cytoskeleton are important for non-typeable Haemophilus influenzae invasion of respiratory epithelial cells. Microbiology 2012, 158, 2384-2398. [CrossRef]

42. Fernandez-Calvet, A.; Rodriguez-Arce, I.; Almagro, G.; Moleres, J.; Euba, B.; Caballero, L.; Marti, S.; Ramos-Vivas, J.; Bartholomew, T.L.; Morales, X.; et al. Modulation of Haemophilus influenzae interaction with hydrophobic molecules by the VacJ/MlaA lipoprotein impacts strongly on its interplay with the airways. Sci. Rep. 2018, 8, 6872. [CrossRef] [PubMed]

43. Barrajon-Catalan, E.; Fernandez-Arroyo, S.; Roldan, C.; Guillen, E.; Saura, D.; Segura-Carretero, A.; Micol, V. A systematic study of the polyphenolic composition of aqueous extracts deriving from several Cistus genus species: Evolutionary relationship. Phytochem. Anal. 2011, 22, 303-312. [CrossRef] [PubMed]

44. DeChiara, M.; Hood, D.; Muzzi, A.; Pickard, D.J.; Perkins, T.; Pizza, M.; Dougan, G.; Rappuoli, R.; Moxon, E.R.; Soriani, M.; et al. Genome sequencing of disease and carriage isolates of nontypeable Haemophilus influenzae identifies discrete population structure. Proc. Natl. Acad. Sci. USA 2014, 111, 5439-5444. [CrossRef] [PubMed]

45. Moleres, J.; Fernandez-Calvet, A.; Ehrlich, R.L.; Marti, S.; Perez-Regidor, L.; Euba, B.; Rodriguez-Arce, I.; Balashov, S.; Cuevas, E.; Linares, J.; et al. Antagonistic pleiotropy in the bifunctional surface protein FadL (OmpP1) during adaptation of Haemophilus influenzae to chronic lung infection associated with chronic obstructive pulmonary disease. MBio 2018, 9. [CrossRef] [PubMed]

46. Pettigrew, M.M.; Ahearn, C.P.; Gent, J.F.; Kong, Y.; Gallo, M.C.; Munro, J.B.; D’Mello, A.; Sethi, S.; Tettelin, H.; Murphy, T.F. Haemophilus influenzae genome evolution during persistence in the human airways in chronic obstructive pulmonary disease. Proc. Natl. Acad. Sci. USA 2018, 115, E3256-E3265. [CrossRef] [PubMed]

47. Morey, P.; Viadas, C.; Euba, B.; Hood, D.W.; Barberan, M.; Gil, C.; Grillo, M.J.; Bengoechea, J.A.; Garmendia, J. Relative contributions of lipooligosaccharide inner and outer core modifications to nontypeable Haemophilus influenzae pathogenesis. Infect. Immun. 2013, 81, 4100-4111. [CrossRef]

48. Rodriguez-Arce, I.; Al-Jubair, T.; Euba, B.; Fernandez-Calvet, A.; Gil-Campillo, C.; Marti, S.; Tornroth-Horsefield, S.; Riesbeck, K.; Garmendia, J. Moonlighting of Haemophilus influenzae heme acquisition systems contributes to the host airway-pathogen interplay in a coordinated manner. Virulence 2019, 10, 315-333. [CrossRef]

49. Rodriguez-Arce, I.; Marti, S.; Euba, B.; Fernandez-Calvet, A.; Moleres, J.; Lopez-Lopez, N.; Barberan, M.; Ramos-Vivas, J.; Tubau, F.; Losa, C.; et al. Inactivation of the thymidylate synthase thy $A$ in non-typeable Haemophilus influenzae modulates antibiotic resistance and has a strong impact on its interplay with the host airways. Front. Cell. Infect. Microbiol. 2017, 7, 266. [CrossRef]

50. Reyes-Farias, M.; Carrasco-Pozo, C. The anti-cancer effect of quercetin: Molecular implications in cancer metabolism. Int. J. Mol. Sci. 2019, 20, 3177. [CrossRef]

51. Townsend, E.A.; Emala, C.W., Sr. Quercetin acutely relaxes airway smooth muscle and potentiates b-agonist-induced relaxation via dual phosphodiesterase inhibition of PLCbeta and PDE4. Am. J. Physiol. Lung Cell. Mol. Physiol. 2013, 305, L396-L403. [CrossRef]

52. Euba, B.; Moleres, J.; Segura, V.; Viadas, C.; Morey, P.; Moranta, D.; Leiva, J.; de-Torres, J.P.; Bengoechea, J.A.; Garmendia, J. Genome expression profiling-based identification and administration efficacy of host-directed 
antimicrobial drugs against respiratory infection by nontypeable Haemophilus influenzae. Antimicrob. Agents Chemother. 2015, 59, 7581-7592. [CrossRef] [PubMed]

53. Fang, Y.; Cao, W.; Xia, M.; Pan, S.; Xu, X. Study of structure and permeability relationship of flavonoids in Caco-2 cells. Nutrients 2017, 9, 1301. [CrossRef] [PubMed]

54. Das, T.; Mukherjee, S.; Chaudhuri, K. Effect of quercetin on Vibrio cholerae induced nuclear factor- $\mathrm{\kappa B}$ activation and interleukin-8 expression in intestinal epithelial cells. Microbes Infect. 2012, 14, 690-695. [CrossRef] [PubMed]

55. Li, G.; Shen, X.; Wei, Y.; Si, X.; Deng, X.; Wang, J. Quercetin reduces Streptococcus suis virulence by inhibiting suilysin activity and inflammation. Int. Immunopharmacol. 2019, 69, 71-78. [CrossRef]

56. Wedzicha, J.A.; Calverley, P.M.; Rabe, K.F. Roflumilast: A review of its use in the treatment of COPD. Int. J. Chron. Obstruct. Pulmon. Dis. 2016, 11, 81-90. [CrossRef]

57. Cosio, B.G.; Jahn, A.; Iglesias, A.; Shafiek, H.; Busquets, X.; Agusti, A. Haemophilus influenzae induces steroid-resistant inflammatory responses in COPD. BMC Pulm. Med. 2015, 15, 157. [CrossRef]

58. Li, H.; Liu, D.H.; Chen, L.L.; Zhao, Q.; Yu, Y.Z.; Ding, J.J.; Miao, L.Y.; Xiao, Y.L.; Cai, H.R.; Zhang, D.P.; et al. Meta-analysis of the adverse effects of long-term azithromycin use in patients with chronic lung diseases. Antimicrob. Agents Chemother. 2014, 58, 511-517. [CrossRef]

59. Boots, A.W.; Haenen, G.R.; Bast, A. Health effects of quercetin: From antioxidant to nutraceutical. Eur. J. Pharmacol. 2008, 585, 325-337. [CrossRef]

60. Wang, L.; Chen, J.; Wang, B.; Wu, D.; Li, H.; Lu, H.; Wu, H.; Chai, Y. Protective effect of quercetin on lipopolysaccharide-induced acute lung injury in mice by inhibiting inflammatory cell influx. Exp. Biol. Med. 2014, 239, 1653-1662. [CrossRef]

61. Wang, X.F.; Song, S.D.; Li, Y.J.; Hu, Z.Q.; Zhang, Z.W.; Yan, C.G.; Li, Z.G.; Tang, H.F. Protective effect of quercetin in LPS-induced murine acute lung injury mediated by cAMP-Epac pathway. Inflammation 2018, 41 , 1093-1103. [CrossRef]

62. Mitani, A.; Azam, A.; Vuppusetty, C.; Ito, K.; Mercado, N.; Barnes, P.J. Quercetin restores corticosteroid sensitivity in cells from patients with chronic obstructive pulmonary disease. Exp. Lung Res. 2017, 43, 417-425. [CrossRef] [PubMed]

63. Heinz, S.A.; Henson, D.A.; Austin, M.D.; Jin, F.; Nieman, D.C. Quercetin supplementation and upper respiratory tract infection: A randomized community clinical trial. Pharmacol. Res. 2010, 62, 237-242. [CrossRef] [PubMed]

64. Pal, A.; Tripathi, A. Quercetin potentiates meropenem activity among pathogenic carbapenem-resistant Pseudomonas aeruginosa and Acinetobacter baumannii. J. Appl. Microbiol. 2019, 127, 1038-1047. [CrossRef] [PubMed]

65. Vipin, C.; Mujeeburahiman, M.; Ashwini, P.; Arun, A.B.; Rekha, P.D. Anti-biofilm and cytoprotective activities of quercetin against Pseudomonas aeruginosa isolates. Lett. Appl. Microbiol. 2019, 68, 464-471. [CrossRef]

66. Zeng, Y.; Nikitkova, A.; Abdelsalam, H.; Li, J.; Xiao, J. Activity of quercetin and kaemferol against Streptococcus mutans biofilm. Arch. Oral Biol. 2019, 98, 9-16. [CrossRef]

67. Sugiyama, T.; Kawaguchi, K.; Dobashi, H.; Miyake, R.; Kaneko, M.; Kumazawa, Y. Quercetin but not luteolin suppresses the induction of lethal shock upon infection of mice with Salmonella typhimurium. FEMS Immunol. Med. Microbiol. 2008, 53, 306-313. [CrossRef]

68. Brown, J.C.; Wang, J.; Kasman, L.; Jiang, X.; Haley-Zitlin, V. Activities of muscadine grape skin and quercetin against Helicobacter pylori infection in mice. J. Appl. Microbiol. 2011, 110, 139-146. [CrossRef]

69. Napimoga, M.H.; Clemente-Napimoga, J.T.; Macedo, C.G.; Freitas, F.F.; Stipp, R.N.; Pinho-Ribeiro, F.A.; Casagrande, R.; Verri, W.A., Jr. Quercetin inhibits inflammatory bone resorption in a mouse periodontitis model. J. Nat. Prod. 2013, 76, 2316-2321. [CrossRef]

70. Tormakangas, L.; Vuorela, P.; Saario, E.; Leinonen, M.; Saikku, P.; Vuorela, H. In vivo treatment of acute Chlamydia pneumoniae infection with the flavonoids quercetin and luteolin and an alkyl gallate, octyl gallate, in a mouse model. Biochem. Pharmacol. 2005, 70, 1222-1230. [CrossRef]

71. Gaschler, G.J.; Skrtic, M.; Zavitz, C.C.; Lindahl, M.; Onnervik, P.O.; Murphy, T.F.; Sethi, S.; Stampfli, M.R. Bacteria challenge in smoke-exposed mice exacerbates inflammation and skews the inflammatory profile. Am. J. Respir. Crit. Care Med. 2009, 179, 666-675. [CrossRef] 
72. Konduru, A.S.; Lee, B.C.; Li, J.D. Curcumin suppresses NTHi-induced CXCL5 expression via inhibition of positive IKK $\beta$ pathway and up-regulation of negative MKP-1 pathway. Sci. Rep. 2016, 6, 31695. [CrossRef] [PubMed]

73. Konduru, A.S.; Matsuyama, S.; Lee, B.C.; Komatsu, K.; Li, J.D. Curcumin inhibits NTHi-induced MUC5AC mucin overproduction in otitis media via upregulation of MAPK phosphatase MKP-1. Int. J. Inflam. 2017, 2017, 4525309. [CrossRef] [PubMed]

74. Contreras, M.; Borras-Linares, I.; Herranz-Lopez, M.; Micol, V.; Segura-Carretero, A. Further exploring the absorption and enterocyte metabolism of quercetin forms in the Caco-2 model using nano-LC-TOF-MS. Electrophoresis 2016, 37, 998-1006. [CrossRef] [PubMed]

75. Herranz-Lopez, M.; Borras-Linares, I.; Olivares-Vicente, M.; Galvez, J.; Segura-Carretero, A.; Micol, V. Correlation between the cellular metabolism of quercetin and its glucuronide metabolite and oxidative stress in hypertrophied 3T3-L1 adipocytes. Phytomedicine 2017, 25, 25-28. [CrossRef]

(C) 2019 by the authors. Licensee MDPI, Basel, Switzerland. This article is an open access article distributed under the terms and conditions of the Creative Commons Attribution (CC BY) license (http://creativecommons.org/licenses/by/4.0/). 